\title{
Teacher as learner: a personal reflection on a short course for South African university educators
}

\author{
Lindsay Clowes
}

\begin{abstract}
Higher education is understood to play a critical role in ongoing processes of social transformation in post-apartheid South Africa through the production of graduates who are critical and engaged citizens. A key challenge is that institutions of higher education are themselves implicated in reproducing the very hierarchies they hope to transform. In this paper, I reflect critically on my experiences of a course aimed at transforming teaching through transforming teachers. In this paper, I foreground my own positionality as a white female educator as I draw on feminist theorising to reflect on my experiences as a learner in the Community, Self and Identity course. I suggest that we need to teach in ways that are more cognisant of the complexities of the constraints on personal freedom in the past if we are to contribute to the development of social justice in the future.
\end{abstract}

\section{Introduction}

The South African context of higher education is one in which global debates around the role of the humanities, impact of market fundamentalism, the corporatisation of the university, role of emerging technologies and so on are complicated by legacies of struggle that continue to be expressed through inequalities structured around gender, sexuality, class, race, ethnicity, generation, disability and religion etc., alongside constitutional and ethical imperatives to challenge such inequalities. South African institutions of higher education have employed a range of strategies and approaches aimed at contributing towards the social transformation eliminating these inequalities requires. An important element of this has been to acknowledge that institutions themselves are implicated in reproducing the very hierarchies that must be challenged. For South African educators, this is a complex and difficult terrain: if we are to develop graduates who are critical and engaged citizens we need to start with ourselves. One innovative response to this has been a collaboration between the Directorate of Teaching and Learning at the University of the Western Cape and the University of Stellenbosch's Centre for Teaching and Learning in the development of a module offered to teachers in institutions of higher education. Underpinning the module was the understanding that the production of graduates who were critically aware citizens required the transformation of teaching practices through the transformation of teachers. In this paper, I reflect on my experiences and learnings as an educator turned student in the Community, Self and Identity (CSI) course of 2010 by drawing on feminist theorising acknowledging the blurring of distinct lines between the 
personal and the professional, and that foregrounds my positionality as a feminist, and as a white, female educator implicated in the hierarchies alluded to above.

\section{South African landscapes of higher education}

Challenges facing educators globally take on very particular flavours in South African contexts of higher education. The transition from a white supremacist regime to a democratic state with a constitutional imperative towards equity has meant that every South African is confronted daily by the challenge of living 'beyond the destructive appeals of their exclusionary pasts' (Soudien 2012, 4). Like other citizens, South African educators are presented, individually and collectively, from one moment to the next, with multiple opportunities from which to 'imagine a future in which the value of being human is primary' (Soudien 2012, 4). South African education - and higher education in particular - is central to this act of imagining, through providing the intellectual insights, motivation and tools to 'trouble' received knowledges that essentialise identities and the corresponding inequalities built around race, gender, sexuality, class, religion and other salient subject locations. For Crain Soudien (2012, 4), South African education represents a 'unique' opportunity 'for rethinking the questions of 'how-to-be' and how human beings can 'be-together' in ways that few other societies in the world are doing'.

Confronting apartheid legacies of inequalities has been central to the development of higher education policy in post-apartheid South Africa (see Lange and Singh 2010), most recently by the appointment of the Oversight Committee on the Transformation of South African Universities (DHET 2013; see also the Mail and Guardian Special Report 2013). Formed on the recommendation of a Ministerial Committee on Transformation and Social Cohesion and the Elimination of Discrimination in Public Higher Education that insisted that 'discrimination, in particular with regard to racism and sexism, is pervasive' in institutions of higher education (DHET 2008, 13), the Oversight Committee is tasked with advising the Minister of Higher Education with regard to elimination of 'racism, sexism and other forms of unfair discrimination' in public universities (DHET 2013, 2). The Oversight Committee emerges out of a long-standing policy emphasis on the centrality of redress and equity in terms of higher education's role in social and political Transformation, alongside recognition that the educational system itself needs to be transformed in order to fulfil its 'immense potential to contribute to the consolidation of democracy and social justice' (CHE 2000, 25 cited in the Draft National Plan 2001, 5). The tensions and fractures permeating the complex terrain within which South African educators operate are exemplified by responses to this initiative: While some academics have welcomed it as a 'long-overdue move', others insist the committee to be nothing more than 'a permanent commissariat to police transformation that will no doubt massacre some universities' (Daily Maverick January 31 2013), and still others warn that 'regulatory overkill threatens academic autonomy' (Business Day live January 31 2013).

\section{Local initiatives}

It is within this uneven and contested terrain that institutional processes of selfconscious reflection on the scholarship and practices of teaching and learning have seen the establishment of structures aimed at deepening transformation within institutions of higher education. In the Western Cape, the Centre for Teaching and Learning was set up 
at the University of Stellenbosch (US) in 2003 and the Directorate of Teaching and Learning established in 2008 at the University of the Western Cape (UWC). Working together on a 'cross-institutional collaborative teaching and learning project promoting inclusivity', these two structures agreed that the overall policy objectives of developing a more critical and transformative system of higher education were constrained by the 'continuing impact of apartheiddesigned segregated higher education institutions and lack of imaginative attention to issues of difference in teaching and learning' as well as a shortage of appropriately equipped educators (Bozalek 2009, 4-5). The 'disjuncture' between 'policy intentions and the actual experiences of students and staff in the higher education sector' (Bozalek 2009, 4-5) combined to limit the development of graduates as 'critical and responsible citizens who contribute to the social and economic well-being of society' (Development of Graduate Attributes at UWC nd:1-2). In order to begin to address this disjuncture, UWC and US collaborated in the development of a module aimed at developing the skills of higher education educators in order to better equip them to produce alumni who were 'engaged, committed and accountable agents of social good [who] aspire to contribute to social justice and care, appreciative of the complexity of historical contexts and societal conditions' (Development of Graduate Attributes at UWC nd:1-2).

The CSI course of 2010 was taught by a team of educators from UWC's Directorate of Teaching and Learning (assisted by a digital media expert), the US Centre for Teaching and Learning, and the US Department of Psychology. Advertised nationally, the course aimed to align the development of educators with the aspirations for graduates articulated in the Charter of Graduate Attributes. Its objectives, as articulated in the course outline, were informed by the belief that developing teachers and transforming teaching practices were central to the development of graduates as critically aware citizens. The teachers who enrolled as learners were to be encouraged to reflect critically on 'notions of community, self and identity in relation to difference and social inclusion in higher education', to 'deepen [their] learning about diversity and difference', enhance their reflexivity and capacity for 'critical questioning as a helpful resource in higher education', to reduce isolation and build community, deepen familiarity with electronic and participatory technologies for creating and sustaining communities as well as to engage with the scholarship of teaching and learning (Course Outline 2010). It was hoped that the experiential and theoretical learning employed by the module would empower participants to '[i]nterrogate the notions of 'social justice', 'community', 'self' and 'identity' through examining own experience [sic], engaging with literature on the topic and sharing ideas across disciplines and institutions with collaborative partners' (Course Outline 2010).

The overall aim of the module, as I understood it, was to engage teachers in critically reflecting on their own prior knowledges and social locations with a view to deepening their understanding of ways in which educators are themselves 'implicated within the social and pedagogical narrative ... themselves carriers of troubled knowledge' (Jansen 2009, 258). This seemed, to me, to be an opportunity to raise awareness 'of the full possibility of what it means to be human', an awareness that is only complete 'when the 
learnt prejudices and false certainties of race and gender and indeed all our unproblematised conceits about who and what we are, are unlearnt' (Soudien 2012, 7). I signed up enthusiastically. This represented an opportunity to enrich my own understandings and in particular to develop my approach to teaching around identities, subjectivities and self that are central to the courses I offer in the Women's and Gender Studies Department at UWC.

\section{The course}

The course began with a two-day meeting in March 2010 at the University of Stellenbosch, and was followed by online interactions and a final two-day meeting in August. With some trepidation (built around expectations of homework, assignments and evaluation processes) I set off, on the appointed day, to meet my colearners. A mixed group of about 20 faculty from a range of institutions and disciplines, we were quickly broken up into smaller groups of about 5 or 6 . At the risk of reinscribing the very identities my own research as an historian aims to deconstruct, we were men and women, straight and gay, of different classes, ethnicities, languages and generations, and, to employ the apartheid categories that continue to have currency, we were 'white', 'black' and 'coloured'.While we were all privileged to have postgraduate educations and to have careers in academia we were not all positioned in the academy in the same way. Some had decades of teaching experience, others were more junior. Some had doctorates and had published; others were busy with their Ph.D.'s. Some were in relatively senior positions; others were much newer to the academy. While some spoke English as their mother tongue, others had English as a second or even a third language. My anxieties dissipated very quickly. In contrast to several participants, I already had my doctoral degree (from the historically white University of Cape Town). I was also clearly amongst the older and more experienced participants and, furthermore, I already had a modest publishing record. The entire proceedings were conducted in English, my mother tongue, and being what the apartheid regime would have classified as 'white', I was able to draw on the privileges that continue to accrue to 'white' South Africans nearly two decades after the shift to democratic rule. In contrast to my co-learners, key social locations consistently positioned me in advantageous and privileged ways.

I imagined that the participatory methodologies employed, that aimed to alert 'participants to privilege and marginalisation through encounters across difference' (Bozalek 2011, 469), would surface these complex positionalities. We began, for example, with our personal histories, and each asked to use colourful oil pastels to draw the 'river of our lives', drawings which were then used as the basis for reflection. In the next exercise, we used the same pastels to map and then discuss 'our community', and in this way the course moved forward. Differences emerged even before we had begun: where I could hardly wait to get my hands on the crayons, others had felt intimidated. One participant noted in an email on 23 October, 2010, that the drawing exercises 'were quite daunting to me', while another observed in an email on 9 April, 2010, that 'the activities were quite unsettling . . . drawing with crayons and such, it is not something I'm familiar with anymore, so it was a bit challenging trying to come up with a "good enough" drawing'. 
In reflecting on the overall experience once the course had ended members of my group agreed in an email on 5 April, 2010, that there had been a 'very strong feeling of collegiality amongst our group'. Another emailed on 22 April 2010, that the course felt as if she were 'involved in a collaborative workshop with colleagues', while a third commented in an email on 22 April, 2010, that it was 'very refreshing to be with a group of people who were broadly interested in the same stuff. In contrast, my experiences were less positive. Although, at the start of the course, I had shared the sense of collegiality described by my colleagues I had felt increasingly uncomfortable as it proceeded. As early as mid-morning of the first day, my sense of belonging had given way to frustration and as the course proceeded my irritation and discomfort mounted.

\section{Tensions and frustrations}

My irritation lay in the fact that we were a group talking about community largely as a metaphor for race where race seemed to be dislocated from other subjectivities. There was little or no discussion of what it might mean, for instance, that only some of us relished the opportunity to use crayons and colour in class and whether or how this might be linked to a wide range of social locations. Instead, we were talking about race, and talking about race without reference to gender or other positionalities. This was amplified by a reading list where questions around race featured strongly, but where just one (out of about 50 recommended articles) made mention of gender in the title. My frustration grew as it became increasingly clear that understandings of race would not be undergoing a critical analysis of the ways in which race itself is a social construct mediated by other constructs.

I found myself, in other words, a feminist in a space devoted to promoting social justice where gender (let alone other subjectivities) was barely acknowledged - and this in a society in which women have been described as 'under siege' (Gqola 2007, see also Lewis 2009; Ratele 2006; Hassim 2009; Gouws 2005; Steyn and van Zyl 2009; Isike and Uzodike 2011; Salo et al. 2010; Hunter 2011; Bak 2008). I found myself furthermore a feminist historian in a space where the centrality of gender and sexuality to racialised and racist processes of imperialism, colonialism, industrialisation, urbanisation and, more recently, apartheid, were dismissed. I found myself in a space where race was the overarching narrative despite work demonstrating how gender and sexuality, expressed through patriarchal masculinities and heteronormativities, are just as important as race in understanding historical practices of race, of warrior traditions, white supremacy, local liberation movements and patriarchal communities that produce and reproduce the profound social injustices characterizing South African society today (see, for example, Scully 1997; van der Spuy 1996; Bradford 1987, 1996; Gevisser and Cameron 1995; Germond and de Gruchy 1997; Achmat 1993; Erlank 2003; Suttner 2009; Unterhalter 2000).

Taking gender (and other positionalities) seriously also means acknowledging that performances of masculinity are deeply harmful to all men, even those occupying locations of privilege. As bel hooks has observed '[p]atriarchy is the single most life threatening social disease assaulting the male body and spirit' (2004, 17; see also Hearn 
2007; Woods 2010). In South Africa though, dominant discourses which essentialise gender simultaneously construct gender equity as a zero sum game in which men have nothing to gain and everything to lose. The biological essentialism underpinning the 'inscribed habits of attention' (Dewey in Boler and Zembylas 2003, 127), that weave together the 'everyday fabric of what is considered common sense' (Boler and Zembylas 2003,111 ) to unmark gender and sexuality, that narrate the injustices of the past almost entirely around race, have little or nothing to offer men. Such a discourse is deeply problematic for questions of social justice. It is, as Yuval-Davis insists, precisely those social divisions that go unmarked or unrecognised that are in fact central, and that to speak about one subject location without reference to another is to risk essentialising both. 'Rendering them visible needs to be an important political project ... recognition of social power, not of social identities - is of crucial emancipatory importance' for all of us (Yuval-Davis 2006, 201).

Silence, in the face of such theorising, did not seem to be a viable option, particularly when complemented with a feminist understanding of silence as a political act for which we are accountable. Speaking out on the other hand also came at a price. In drawing on the theorising alluded to above, I suggested that it was important we recognise that racialised subjectivities were co-constructed by gender, sexuality and other salient subject positions. My teachers responded by explaining that South Africa's history of racial inequality meant it was both necessary and desirable to concentrate on racial inequalities. I insisted that we risked essentialising race, gender and heteronormativity, unless we acknowledged the ways in which subjectivities mediate and co-construct each other. My teachers explained again that the course was focused on differences structured around race. With this disagreement underpinning interactions over the course of the entire module, I increasingly felt myself positioned as the stereotypical 'white woman who doesn't want to talk about race'. What felt like a negation of both my teaching and my personal belief system produced what could be described as a panic attack, such that by the end of the course, even though all those around me remained gracious, I was, to say the least, deeply discomforted.

\section{Learning through discomfort}

In reflecting on the cause and level of irritation, frustration and panic, I experienced I was reminded of the experiences of a colleague almost a decade earlier when he and I were members of a group of 10 feminist academics from the Universities of the Western Cape and the West Indies invited to a Summer Institute at the Women's Studies Department of the University of Maryland, College Park, USA. We spent just over two weeks in often heated discussion and debate with our hosts and colleagues, all bar one of whom were women. The solitary man was Kopano Ratele, a feminist psychologist then based at UWC. He subsequently wrote a paper about the discomforts he experienced at being the only man in the group, and how it felt as if he had 'walked in where one is not supposed to be, akin to crashing an intimate dinner, but somehow the couple goes on being extremely and inexplicably nice, as if they had been expecting you' (Ratele 2001, 77). The paper, in which he drew critical attention to a complex set of emotional attachments expressed as, or through, boundaries of belonging, raises questions about the 'anxieties of belonging' or 
not belonging, and how we come to not belong, to get 'lost', suddenly struck home (Ratele 2001, 82).

At the Summer Institute it was Ratele's gender, his social positioning (which coincided with self-identification) as 'man', which trumped his sense of self as a feminist academic, and that compromised his sense of feeling at home. In the CSI module, it was my social positioning as 'white', compounded by popular understandings of feminist ideology as a divisive and largely irrelevant Western import (Hassim 2009), that compromised my sense of belonging. For Ratele, belonging meant to conform and he drew attention to how the inevitable disavowal of difference that accompanies conforming meant that ' $[t]$ he kind of belonging one wishes for . . is one that is permanently suspended, always negotiable' (2001, 82). 'Belonging', in other words, requires concessions, a willingness to give up difference. The difficulty confronting both of us, though, was that even though, like Ratele, I understand race and gender as social constructs, the social positioning they entail is not easily given up.

At the same time, a key component of being 'lost', according to Ratele, lay in being unable to understand, or in misunderstanding, others (Ratele 2001, 78). I wondered about this in relation to my response to feeling 'lost', and the ways in which being unable to make my point heard - that gender and sexuality matter - had compromised my ability to inhabit a feminist identity. Perhaps, in naming my experiences as 'frustration' and 'irritation' I was in fact occupying a location of privilege structured around some or all of the subject locations I identified earlier in this paper. Renaming and reconceiving my responses as 'anxieties' suggested new questions to ask about my engagement with the module, compelling me to think much more carefully about how to understand the overall experience. In locating me in a marginal space and raising questions about the deeply held feminist beliefs informing both my teaching and research, in requiring me to think more carefully about the tensions implicit in Patti Lather's (2001) suggestion that nonmastery is an ethical move, the course certainly elicited the discomfort and careful consideration that provided me with space to reflect and ultimately to a deeper understanding - and stronger commitment - to my feminism. For that, I thank my teachers.

\section{Reflecting on pedagogy}

Perhaps, the anxiety and panic I felt during the course were an expected and necessary outcome of the pedagogical approach deliberately employed by the course convenors. They had hoped to explore difference by adopting what Megan Boler and Michalanos Zembylas have termed a 'pedagogy of discomfort' $(2003,129)$. Such a pedagogy 'urges students as well as educators to move outside of their comfort zones . . . [and] invites critical inquiry regarding cherished beliefs and assumptions' (Boler and Zembylas 2003, 131). The course certainly achieved that, as evidenced by this paper.

The challenge, however, of teaching for transformation while transforming teaching remains. The difficult times within which South African educators such as myself labour remains characterised by paradox: nothing is resolved. On the one hand, power inequalities shaped by imperialism and colonialism and created in law under apartheid as 
'race' have been and remain an important explanatory narrative in South African history. Today many, if not most, South Africans use these categories to self-identify because they have shaped individual lives in meaningful ways and because they continue to serve as both constraints and resources in everyday interactions (Whitehead 2012; Hunter 2011; Seekings 2008; Adhikari 2004). The need, in post-apartheid South Africa, to evaluate change in terms of equity and redress for specific groups further reinscribes the use of race. South African academics (myself included) still use the racialised categories1 with which we are familiar precisely because they continue to have saliency. As Yuval-Davis observes '[i]n specific historical situations and in relation to specific people' there are 'social divisions that are more important than others in constructing individuals' specific positionings' (2006, 201). To jettison the racial categories with which so many South Africans still identify would represent an elision of profoundly significant experiences of difference, exclusion and struggle.

At the same time however, uncritical deployment of the racial categories invented over centuries of struggle means glossing over the ways in which such identities are always social constructs, always contested, even in their most stable and 'primordial forms' (Yuval-Davis 2006, 199). It is deeply problematic that we continue, as Ratele notes, to 'deploy race as a fact of nature, act as if sex and gender at some moments are unraced, and almost always completely ignore desire, or at best keep it separate from, the politics of race, and similarly sex and gender' (2004, 140, original strikethrough). Perhaps, this helps explain why (in the US at least) students engaged in diversity classes focusing on race and ethnicity are apparently not learning about and from diversity (Barnet 2011, 671). Closer to home, Lange and Singh (2010) have also drawn attention to limitations associated with privileging one aspect of identity in their discussion of the South African educational landscape.

More alarming still is the risk of validating such inventions in contemporary nationalisms (see Robus and Macleod 2006). If we are to heed Paul Zeleza's warning that ' $[\mathrm{t}]$ he pages of history drip with blood shed by invented identities' $(2006,15)$, then such nationalisms must be opened to critique. Taking gender, sexuality as well as race and other axes of power and privilege seriously, exploring how they mediate and co-construct each other presents possibilities for understanding the past - and imagining the future - differently. How, for example, might understanding the conflict characterising centuries of South African history as a conflict between racialised versions of heterosexual patriarchal masculinity shape how we teach South African history? How might such teaching shape how our graduates understand social justice and how they might imagine South African citizenship in the future?

It is, as Forrest reminds us, precisely those unmarked categories that need to be surfaced. A key goal of critical pedagogy should be to raise awareness of the structures that hold us back from within, to provide space for surfacing complexity and to create space within which teachers and learners are able to challenge their own interpretations of reality (Forrest, Judd, and Davison 2012). The importance of recognising this complexity was underlined by a comment from a gender diverse reader of this paper, a transperson whose 
embodiment challenges hegemonic understandings of both sex and gender. My experiences of the CSI module reminded him of the 'trauma and emotional exhaustion ... [of] a gender reconciliation breathwork workshop of about 30 people' about 10 years ago. 'For most exercises', he recalled 'women and men were divided into separate groups. I was having to fight all the way to try and undermine the binary discourse - the whole way it reinforced gender stereotypes, heteronormativity, etc'. Eventually he told them, 'well, I don't belong to either of the two groups, so I guess I'll have to make my own group and sit by myself and think about gender diversity. Actually I was kinda ready to bolt.' After making this decision, he was surprised to find a few others wanting to join his group 'because it sounds more interesting'. In the end, this small group included 'individuals from four sex/gender identities (transgender, intersex, female and male), at least three sexual orientations (straight, personality-oriented, asexual), three language groups, three racial backgrounds (black, coloured, white), ages ranging from twenties to sixties and included wheelchair users as well as able-bodied individuals (as noted by ES in a comment on a draft of the paper on 28 July, 2012, see also Morgan, Marais, and Wellbeloved 2009; Morgan and Wieringa 2005).

\section{Conclusion}

The difficult times within which South African educators labour, and the more inclusive and transformative education system these times demand, requires more (rather than less) recognition of the social complexity of both the past and the present. Addressing the profound inequalities structured around gender, sexuality and class that co-construct and intersect with race requires the disruption of monolithic and essentialising narratives around race and this needs to permeate our teaching. My undergraduate students have taught me how difficult they find it to see this complexity, how hard they find it to understand gender, sexuality or race as socially constructed expressions of power, of privilege and marginalisation. Despite extensive exposure to gender theorising, interactions with students reveal that even at the end of a course on gender, masculinity can remain largely unmarked (see Clowes 2013). And yet, a future characterised by social justice demands a full understanding of injustice in the past: there is, as Ursula le Guin once said, 'no road, nowhere to go ... unless the past and the future [are] made part of the present by memory and intention' (Le Guin 1974, 157).

In the last two years, my undergraduate classes have increasingly focused on locations of privilege rather than oppression. I ask my students to explore privilege by drawing on their lived experiences of race, gender, sexuality, class, age, ethnicity, religion (and other subject locations they suggest matter) to consider how they might be privileged and, concomitantly, ways in which their privileges are simultaneously mediated or limited. How, for example, are the patriarchal privileges accruing to male students mediated by race and sexuality? How do race and sexuality intersect with gender to profoundly compromise men's health and well-being, and how do we make sense of this in relation to building a South Africa characterised by social justice? I hope, in 2013, to encourage my students to imagine the kinds of communities they would like to live in in the future, the roles gender, race and other forms of diversity might play (if any?) in these communities, and ways in which they themselves feel constrained or empowered to contribute towards 
the development of such communities. Perhaps in this I might engage with the call, made over a decade ago by Duncan Brown, for teaching and research that reconciles the demands of difference and national belonging 'not through the fictions of imagined unity, but through a shared problematic' (Brown 2001, 767; Kerner 2012, 211). South African educators need to find ways of talking about a shared future without reinscribing the same 'habits of practice' that constitute the very hegemonic discourses of inequality that require critique. Difficult times indeed for South African educators, but as Sheldon Kopp $(1974,166)$ so succinctly observed, while 'you can't get there from here ... there's no place else to go'.

\section{Acknowledgements}

This work is based upon research supported by the National Research Foundation. Thanks to ES, Patricia van der Spuy, Viv Bozalek and Brenda Liebowitz and anonymous reviewers for helpful comments on earlier incarnations of this paper. Thanks also to Anthea Lesch (University of Stellenbosch), Linda Smith (University of the Witwatersrand), Jeff Jawitz (University of Cape Town), Melanie Petersen (University of Stellenbosch) and Sandra Johnson (Cape Peninsula University of Technology) for giving me permission to share some of their experiences of this course.

Note

1. Using inverted commas to signal our discomfort and a footnote to articulate our reservation. 


\section{References}

Achmat, Z. 1993. "“Apostles of Civilised Vice': 'Immoral Practices' and 'Unnatural Vice' in South African Prisons and Compounds, 1890-1920.” Social Dynamics 19 (2): 92110. doi:10.1080/02533959308458553.

Adhikari, M. 2004. "Not Black Enough: Changing Expressions of Coloured Identity in Postapartheid South Africa." South African Historical Journal 51 (1): 167-178. doi:10.1080/02582470409464835.

Bak, M. 2008. "Townships in Transition: Women's Caring Keeps the Township Together." Journal of Southern African Studies 34 (2): 255-268. doi:10.1080/03057070802037928.

Barnet, P. E. 2011. "Discussions Across Difference: Addressing the Affective Dimensions of Teaching Diverse Students About Diversity." Teaching in Higher Education 16 (6): 669-679. doi:10.1080/13562517.2011.570435.

Boler, M., and M. Zembylas. 2003. "Discomforting Truths: The Emotional Terrain of Understanding Difference." In Pedagogies of Difference: Rethinking Education for Social Change, edited by P. Trifonas, 110-136. New York: RoutledgeFalmer.

Bozalek, V. 2009. Community, Self and Identity: A Cross-institutional Collaborative Teaching and Learning Project Promoting Inclusivity. http://sanord.uwc.ac.za/usrfiles/users/9174080913/Conference_2009/V_Bozale k.pdf.

Bozalek, V. 2011. “Acknowledging Privilege through Encounters with Difference: Participatory Learning and Action Techniques for Decolonising Methodologies in Southern Contexts.” International Journal of Social Research Methodology 14 (6): 469-484. doi:10.1080/13645579.2011.611383.

Bradford, H. 1987. “We Are Now the Men': Women's Beer Protests in the Natal Countryside, 1929." In Class, Community and Conflict, edited by B. Bozzoli, 292323. Johannesburg: Ravan Press.

Bradford, H. 1996. "Women, Gender and Colonialism: Rethinking the History of the British Cape Colony and its Frontier Zones, C. 1806-1870." Journal of African history 37 (3): 351-370. doi:10.1017/Soo21853700035519.

Brown, D. 2001. "National Belonging and Cultural Difference: South Africa and the Global Imaginary." Journal of Southern African Studies 27 (4): 757-769. doi:10.1080/03057070120090727.

Business Day live January 31. 2013. "Regulatory Overkill Threatens Academic Autonomy in South Africa." http://www.bdlive.co.za/opinion/2013/o1/31/regulatoryoverkill-threatensacademic-autonomy-in-south-africa.

CHE (Council on Higher Education). 2000. Towards a New Higher Education Landscape: Meeting the Equity, Quality and Social Development Imperatives of South Africa in the $21^{\text {st }} \quad$ Century. Pretoria: http://www.che.ac.za/documents/dooooo9/New_HE_Landscape.pdf.

Clowes, L. 2013. "The Limits of Discourse: Masculinity as Vulnerability." Agenda: Empowering Women for Gender Equity 27 (1): 12-19. doi:10.1080/10130950.2013.778621.

Course Outline. 2010. Course Outline Community, Self and Identity in Higher Education 2010. University of the Western Cape \& University of Stellenbosch. 
Daily Maverick January 31. 2013. "Conversations: Crain Soudien on South Africa's Identity Politics.” http://dailymaverick.co.za/article/2013-01-31-conversationscrain-soudien-on-sasidentity-politics.

DHET. 2008. Report of the Ministerial Committee on Transformation and Social Cohesion and the Elimination of Discrimination in Public Higher Education Institutions. Pretoria: Department of Higher Education and Training. http://uscdn.creamermedia.co.za/assets/articles/attachments/21831_racismreport.pdf.

DHET. 2013. Media Statement: Announcement of the Oversight Committee on the Transformation of South African Universities in Johannesburg, 24 January 2013. Pretoria: Department of Higher Education and Training. Draft National Plan for Higher Education in South Africa, Ministry of Education, 2001. http://www.dhet.gov.za/LinkClick.aspx?fileticket_TRydBRRtaTc\%3D\&tabid_411 \&mid_1369.

Erlank, N. 2003. "Gender and Masculinity in South African Nationalist Discourse, 19121950.” Feminist $\quad$ Studies $\quad 29 \quad$ (3): http://www.jstor.org/discover/10.2307/3178733? uid $=3739368 \&$ uid $=2134 \&$ uid $=2$ \&uid $=70 \&$ uid $=4 \&$ sid $=21102616100427$.

Forrest, K. A., K. R. Judd, and J. R. Davison. 2012. "Coming to Know Within 'Healthy Uncertainty': An Autoethnography of Engagement and Transformation in Undergraduate Education." Teaching in Higher Education 17 (6): 710-721. doi:10.1080/13562517.2012.666733.

Germond, P., and S. de Gruchy. 1997. Aliens in the Household of God: Homosexuality and Christian Faith in South Africa. Cape Town: David Philip.

Gevisser, M., and E. Cameron. 1995. Defiant Desire: Gay and Lesbian Lives in South Africa. Braamfontein: Ravan Press.

Gouws, A., ed. 2005. Unthinking Citizenship: Feminist Debates in Contemporary South Africa. Cape Town: UCT Press.

Gqola, P. 2007. "How the 'Cult of Femininity' and Violent Masculinities Support Endemic Gender based Violence in Contemporary South Africa.” African Identities 5 (1): 111-124. doi:10.1080/14725840701253894.

Hassim, S. 2009. "Democracy's Shadows: Sexual Rights and Gender Politics in the Rape Trial of Jacob Zuma." African Studies 68 (1): 57-77. doi:10.1080/00020180902827431.

Hearn, J. 2007. “The Problems Boys and Men Create, the Problems Boys and Men Experience." In From Boys to Men: Social Constructions of Masculinity in Contemporary Society, edited by T. Shefer, K. Ratele, A. Strebel, N. Shabalala, and R. Buikema, 13-33. Cape Town: UCT Press.

hooks, b. 2004. The Will to Change. New York: Washington Square Press.

Hunter, M. 2011. "Beneath the 'Zunami': Jacob Zuma and the Gendered Politics of Social Reproduction in South Africa.” Antipode 43 (4): 1102-1126. doi:10.1111/j.14678330.2010.00847.x.

Isike, C., and U. Uzodike. 2011. "Marginalising Women in Politics: Recent Trends in KwaZulu-Natal." Development Southern Africa 28 (2): 225-240. doi:10.1080/0376835X.2011.570069. 
Jansen, J. 2009. Knowledge in the Blood: Confronting Race and the Apartheid Past. Stanford, CA: Stanford University Press.

Kerner, I. 2012. "Questions of Intersectionality: Reflections on the Current Debate in German Gender Studies.” European Journal of Women's Studies 19 (2): 203-218. doi:10.1177/1350506811434666.

Kopp, S. 1974. If you Meet the Buddha on the Road, Kill Him! London: Sheldon Press.

Lange, L., and M. Singh, 2010. "Issues in Quality Assurance in South African Higher Education." In Equity and Quality Assurance: A Marriage of Two Minds, edited by M. Martin, 37-73. Paris: UNESCO and International Institute for Educational planning.

Lather, P. 2001. "Postbook: Working the Ruins of Feminist Ethnography." Signs: A Journal of Women in Culture and Society 27 (1): 199-227. doi:10.1086/495677.

Le Guin, U. 1974. The Dispossessed. St Albans: Granada.

Lewis, D. 2009. "Gendered Spectacle: New Terrains of Struggle in South Africa." In Body Politics and Women Citizens: African Experiences, edited by A. Schyler, 125-137. Stockholm: Sida Studies No. 24.

Mail and Guardian Special Report January 28. 2013. Crisis in Humanities. http://mg.co.za/specialreport/crisis-in-humanities.

Morgan, R., C. Marais, and J. Wellbeloved. 2009. Trans: Transgender Life Stories from South Africa. Johannesburg: Jacana Media.

Morgan, R., and S. Wieringa. 2005. Tommy Boys, Lesbian Men and Ancestral Wives: Female Same Sex Practices in Africa. Johannesburg: Jacana Media.

Ratele, K. 2001. "Notes on the Anxieties of Belonging." Agenda 50: 77-82. doi:10.1080/10130950.2001.9675996.

Ratele, K. 2004. "Kinky Politics." In Re-thinking Sexualities in Africa, edited by S. Arnfred, 139-154. Sweden: Almqvist \& Wiksell Tryckeri AB.

Ratele, K. 2006. "Ruling Masculinity and Sexuality." Feminist Africa 6: 48-64. http://agi.ac.za/sites/agi.ac.za/files/fa_6_feature_article_4.pdf.

Robus, D., and C. Macleod. 2006. "White Excellence and Black Failure': The Reproduction of Racialised Higher Education in Everyday Talk." South African Journal of Psychology 36(3): 463-480. doi:10.1177/008124630603600303.

Salo, E., M. Ribas, P. Lopez, and M. Zamboni. 2010. "Living Our Lives on the Edge: Power, Space and Sexual Orientation in Cape Town Townships, South Africa." Sexuality Research and Social Policy 7 (4): 298-309. doi:10.1007/s13178-0100028-8.

Scully, P. 1997. Liberating the Family: Gender and the British Slave Emancipation in the Rural Western Cape, South Africa, 1823-1853. Cape Town: David Philip.

Seekings, J. 2008. "The Continuing Salience of Race: Discrimination and Diversity in South Africa." Journal of Contemporary African Studies 26 (1): 1-25. doi:10.1080/02589000701782612.

Soudien, C. 2012. Realising the Dream: Unlearning the Logic of Race in the South African School. Cape Town: HSRC Press.

Steyn, M., and M. van Zyl. 2009. The Prize and the Price: Shaping Sexualities in South Africa. Cape Town: HSRC Press. 
Suttner, R. 2009. "The Jacob Zuma Rape Trial: Power and African National Congress (ANC) Masculinities." Nordic Journal of Feminist and Gender Research 17 (3): 222-236. doi:10.1080/08038740903117174.

Unterhalter, E. 2000. "The Work of the Nation: Heroic Masculinity in South African Autobiographical Writing of the Anti-apartheid Struggle." European Journal of Development Research 12 (2): 157-178. doi:10.1080/09578810008426770.

Van der Spuy, P. 1996. "Making Himself Master: Galant's Rebellion Revisited." South African Historical Journal 34 (1): 1-28. doi:10.1080/02582479608671862.

Whitehead, K. 2012. "Racial Categories as Resources and Constraints in Everyday Interactions: Implications for Racialism and Non-racialism in Post-apartheid South Africa." Ethnic and Racial Studies 35 (7): 1248-1265. doi:10.1080/01419870.2011.591407.

Woods, J. 2010. "The Black Male Privileges Checklist." In Privilege: A Reader, 2nd ed., edited by M. Kimmel and A. Ferber, 27-37. Boulder, CO: Westview Press.

Yuval-Davis, N. 2006. "Belonging and the Politics of Belonging." Patterns of Prejudice 40 (3): 197-214. doi:10.1080/00313220600769331.

Zeleza, P. 2006. "The Inventions of African Identities and Languages: The Discursive and Developmental Implications." In Selected Proceedings of the 36th Annual Conference on African Linguistics, edited by O. Arasanyin and M. Pemberton, 1426. Somerville, MA: Cascadilla Proceedings Project. http://www.lingref.com/cpp/acal/36/paper1402.pdf. 